\title{
Latest Insights on Food Protein-Induced Enterocolitis Syndrome: An Emerging Medical Condition
}

\author{
Vila Sexto L \\ Pediatric Allergy Department, Children's Hospital Teresa Herrera, La Coruña, Spain
}

J Investig Allergol Clin Immunol 2018; Vol. 28(1): 13-23

doi: 10.18176/jiaci.0192

\begin{abstract}
Food protein-induced enterocolitis syndrome (FPIES) is a type of non-lgE-mediated gastrointestinal food hypersensitivity characterized by profuse vomiting that is frequently associated with pallor or/and lethargy and appears within 1 to 3 hours after ingestion of the offending food. A less frequent chronic form of FPIES is characterized by protracted vomiting, diarrhea, or both accompanied by poor growth. Although FPIES is considered a rare allergic disorder, increasing reports in recent years point to a real increase in incidence, or at least an increased awareness of this condition by pediatricians.

The foods most frequently implicated are cow's milk, soy formula, grains, and fish, depending on the geographic area. Diagnosis is based on clinical manifestations and requires a high index of suspicion, since we still lack a diagnostic laboratory tool. Early recognition of FPIES and removal of the offending food are mandatory. International consensus guidelines on diagnosis and management have been published. Prognosis is usually good, with most children tolerating foods before 6 years of age.
\end{abstract}

Key words: FPIES. Food-induced enterocolitis. Food allergy. Ondansetron. Oral food challenge. Cow's milk. Fish.

\section{Resumen}

La enterocolitis inducida por proteínas de alimentos es un tipo de enfermedad alérgica gastrointestinal no mediada por IgE. Se caracteriza por vómitos profusos, frecuentemente asociados a palidez y/o letargia que aparece 1-3 horas después de la ingesta del alimento al que el paciente se encuentra sensibilizado. Existe otra forma menos frecuente y más larvada o crónica, caracterizada por vómitos persistentes y/o diarrea, asociados a fallo de medro.

Aunque se considera una patología alérgica infrecuente, en los últimos años se ha incrementado el número de publicaciones sobre este tema, indicando si no un incremento real en su incidencia, al menos un incremento en el conocimiento que los pediatras y alergólogos tienen sobre esta enfermedad.

Los alimentos implicados con mayor frecuencia son leche de vaca, soja, cereales y pescado, dependiendo de las distintas zonas geográficas. El diagnóstico se fundamenta en la clínica y por tanto requiere un alto índice de sospecha, dado que no existe ninguna prueba de laboratorio que sea definitiva. Una vez establecido el diagnóstico, es fundamental retirar el alimento de la dieta. Recientemente ha sido publicado un consenso internacional de expertos, en el que se revisa en profundidad el diagnóstico y tratamiento de la enterocolitis. El pronóstico suele ser bueno, ya que la mayoría de los niños llegan a tolerar el alimento antes de los 6 años.

Palabras clave: FPIES. Enterocolitis inducida por alimentos. Alergia alimentaria. Ondansetron. Prueba de exposición controlada oral. Leche de vaca. Pescado. 


\section{Introduction}

Food protein-induced enterocolitis syndrome (FPIES) is a type of non-IgE-mediated gastrointestinal food hypersensitivity characterized in its acute form by profuse vomiting that is frequently associated with pallor or/and lethargy and appears within 1 to 3 hours after ingestion of the offending food. Chronic FPIES presents with protracted vomiting, diarrhea, or both accompanied by poor growth.

FPIES is a relatively new condition. It was first reported in 1967 by Gryboski [1], who described a series of infants presenting during the first 6 weeks of life with recurrent vomiting, bloody diarrhea, abdominal distension, and, occasionally, dehydration while being fed with cow's milk (CM)-based formula. Patients improved with hydrolyzed casein-based formula and experienced recurrence of severe emesis 1 to 3 hours after reintroduction of CM-based formula. In 1978, Powell [2] described 9 newborns presenting with projectile vomiting and severe diarrhea after ingestion of $\mathrm{CM}$ and soy-based formulas. Patients recovered on a CM- and soyfree diet, and symptoms recurred from 1 to 10 hours during food challenge, thus confirming the diagnosis. Based on his experience, Powell proposed clinical diagnostic criteria for FPIES and a standard challenge protocol [2] that has been modified over time by other authors.

\section{Epidemiology}

Although FPIES is considered a rare allergic disorder, the increasing number of reports in the last few years point to a real increase in incidence, or at least an increased awareness of this condition by pediatricians.

Large population studies to assess the overall prevalence of FPIES are lacking. Katz et al [3] were the first to perform a population-based case study with more than 13000 prospectively enrolled Israeli infants. The authors reported a cumulative incidence of CM FPIES of $0.34 \%$ compared with $0.5 \%$ of IgE-mediated CM allergy during the first year of life.

In the UK, Ludman et al [4] reported an incidence of $0.36 \%$ after performing a retrospective audit of patients presenting at a tertiary London pediatric allergy service. In Italy, Sopo et al [5] estimated a prevalence of FPIES of around $1 \%$ based on cases presenting at a pediatric allergy outpatients clinic. A recent Australia-wide survey undertaken through the Australian
Paediatric Surveillance Unit revealed an incidence of FPIES in children less than 2 years of age of 15.4 cases per 100000 inhabitants per year [6].

Although FPIES is considered a pediatric disease, which typically presents during infancy and to some extent during childhood, reports of adult FPIES indicate that it may develop at any age [7]. Most case series report a slight male predominance.

As for atopic background, frequency varies depending on geographical area. In Europe, specifically in Spain and Italy, up to $20 \%-42.7 \%$ of patients report a family history of atopy [5,8-10] while in the United States and Australia, this percentage is higher. In the United States, Caubet et al [11] and Nowak-Wegrzyn et al [12], respectively, reported that $77 \%$ and $71 \%$ of children had a family history of atopy. In Australia, Mehr et al [6] reported that $57 \%$ of children had a family history of atopy.

Eczema has been reported in 9\%-65\% of FPIES patients, asthma in 6\%-28\%, and IgE-mediated food allergy in $11 \%$ $34 \%[5,8-10,12-14]$.

\section{Clinical Presentation}

The first manifestations of FPIES usually develop after the first or second time the offending food is introduced into the infant's diet $[3,5,6]$, although it is only after a mean of 2 episodes (range, 1-6) that the actual diagnosis is finally made $[9,10,12,15,16]$.

FPIES may present in an acute or chronic form. Acute FPIES is the commonest type and usually presents in older infants, children, and adults after intermittent ingestion of the offending food. It is characterized by profuse, projectile, and repetitive emesis frequently accompanied by pallor and lethargy, beginning 1 to 4 hours after ingestion, although it may develop as soon as half an hour or as late as 6 hours after ingestion. Diarrhea may follow within 2 to 10 hours, especially in severe reactions $[17,18]$. Stools may contain blood and mucous. The most common symptoms of acute FPIES are summarized in Table 1.

Chronic FPIES occurs when the culprit food is introduced early in life, usually during the first 4 months, and intake is daily. In this form of presentation, CM- and soy-based formulas are the most frequently implicated foods. Patients develop intermittent emesis, bloody diarrhea, lethargy, dehydration,

Table 1. Clinical Manifestations of Food Protein-Induced Enterocolitis Syndrome ${ }^{a}$

\begin{tabular}{|c|c|c|c|c|c|c|c|c|c|}
\hline & $\begin{array}{c}\text { Katzl } \\
{[3]} \\
(\mathrm{N}=44)\end{array}$ & $\begin{array}{c}\text { Sopo } \\
{[5]} \\
(\mathrm{N}=66)\end{array}$ & $\begin{array}{c}\text { Sicherer } \\
{[64]} \\
(\mathrm{N}=22)\end{array}$ & $\begin{array}{c}\text { Ruiz-García } \\
{[22]} \\
(\mathrm{N}=16)\end{array}$ & $\begin{array}{l}\text { Ludman } \\
\qquad 4] \\
(\mathrm{N}=54)\end{array}$ & $\begin{array}{c}\text { Caubet } \\
{[11]} \\
(\mathrm{N}=74)\end{array}$ & $\begin{array}{c}\text { Nowak-Wegrzyn } \\
{[11]} \\
(\mathrm{N}=14)\end{array}$ & $\begin{array}{c}\text { Vila } \\
{[10]} \\
(\mathrm{N}=21)\end{array}$ & $\begin{array}{c}\text { Zapatero } \\
{[9]} \\
(\mathrm{N}=14)\end{array}$ \\
\hline Vomiting & $100(44)$ & $98(65)$ & $95(21)$ & $100(16)$ & $81(44)$ & $96(70)$ & $100(14)$ & $100(21)$ & $85(12)$ \\
\hline Lethargy & 77 (34) & - & $36(8)$ & $25(4)$ & $17(9)$ & $7(5)$ & $71(10)$ & $66(14)$ & $21(3)$ \\
\hline Pallor & $14(6)$ & $80(53)$ & - & $19(3)$ & $15(8)$ & - & - & $52(11)$ & - \\
\hline Hypotension & - & $77(51)$ & $9(2)$ & - & - & $19(14)$ & $21(3)$ & - & - \\
\hline Diarrhea & $25(11)$ & $54(36)$ & 72 (16) & $56(9)$ & $37(20)$ & $7(5)$ & & $33(7)$ & $35(5)$ \\
\hline
\end{tabular}

avalues are shown as percentage (number of patients). 
abdominal distension, hypoalbuminemia, and failure to thrive. Avoidance of the offending food leads to resolution of symptoms in days, and reintroduction of the food induces an acute FPIES reaction.

FPIES in exclusively breastfed infants is rare, and few cases of CM- or soy-induced FPIES in exclusively breastfed infants have been described [6,19-21]. Breast milk may have a protective effect based on the presence of $\operatorname{IgA}$, the fact that the food is highly processed, and the fact that the amount of the food present in breast milk may be insufficient to elicit symptoms.

\section{Foods Causing FPIES}

$\mathrm{CM}$ is the most frequent cause of FPIES throughout the world. Soy formula is another common trigger of FPIES in the USA [11,14], but not in other areas of the world, such as Europe [5,8,9,22], Australia [6,15], and Israel [3].

As for solid foods, cereals are the principal cause of FPIES in the USA (oats and rice) $[11,12,14]$ and Australia (rice) $[6,13,24]$, while in Europe, especially Spain and Italy, fish is the most widely reported solid food causing FPIES $[4,5,8,10,15,22]$. The wide variety of foods reported includes egg, poultry meat, vegetables (sweet potato, squash, pumpkin, corn, carrots), legumes (green pea, peanut, lentil, kidney bean), fruits (banana, orange, pineapple, apple, tomato, strawberry) [23], mushrooms [25], and even the probiotic Saccharomyces boulardii [2]. Seafood and egg seem to be the main triggers of FPIES in adults $[7,27,28]$.

The most common food triggers in cohort studies are summarized in Table 2.

Patients with CM and soy FPIES present earlier than those with solid food FPIES, since formulas are introduced before solids in infants' diet.

Threshold doses of foods causing FPIES are usually in the gram range, in contrast with IgE-mediated food allergy. However, some children react to casein in hydrolyzed formula and to $\mathrm{CM}$ that passes through breast milk, as previously mentioned.

\section{Multiple Foods Causing FPIES}

In the USA, Ruffner et al [14] and Caubet et al [11], respectively, reported that $43.5 \%$ and $35 \%$ of patients with CM FPIES also reacted to soy. These observations differ from those made in Israel, Spain, Italy, and Australia, where most patients with CM FPIES tolerate soy $[3,5,6,8,15]$

There are also geographical differences in the number of foods involved. In the USA, Nowak-Wegrzyn [12] reported that $80 \%$ of infants reacted to more than 1 food, with $65 \%$ previously diagnosed with CM and/or soy FPIES. In Australia and Europe, only 7\%-33\% of infants with solid food FPIES reacted to more than 1 type of food [6,23]. In Spain, we found only 2 patients out of 21 reacting to 2 different foods: Vazquez et al [8] reported only 1 child out of 81 with FPIES reacting to more than 1 food, and Infante et al [15] reported 9 out of 80 children with fish-induced FPIES reacting to other types of food.

Mehr et al [6] recently reported that infants with FPIES to grains were likely to have co-associated FPIES to fruits, vegetables, or both.

The percentage of patients with FPIES reacting to 2 or more foods is summarized in Table 3.

Differences in FPIES triggers between countries may be explained at least in part by feeding practices. Soy formula is much more commonly used in the USA than in Europe and Australia, and Australian and European feeding guidelines do not recommend the use of soy formula in children under 6 months of age, whereas American guidelines make no restrictions [29].

On the other hand, although rice is one of the first solid foods introduced in the infant diet, FPIES caused by rice is reported mainly in Australia and the USA, but not in Europe, where fish is the main solid food causing FPIES. Thus, other environmental or genetic factors could be involved in this geographical variability regarding FPIES triggers.

Katz et al [3] and Sopo et al [5] support the theory of different phenotypes of FPIES, which would explain differences in food triggers, prevalence of allergic family histories, and range of severity of reactions.

Table 2. Most Common Food Triggers of Food Protein-Induced Enterocolitis Syndrome in Cohort Studies

\begin{tabular}{|c|c|c|c|c|c|c|c|c|c|}
\hline & $\begin{array}{c}\text { Caubet } \\
{[11]} \\
(\mathrm{N}=160)\end{array}$ & $\begin{array}{c}\text { Ruffner } \\
{[14]} \\
(\mathrm{N}=462)\end{array}$ & $\begin{array}{c}\text { Sicherer } \\
{[64]} \\
(\mathrm{N}=22)\end{array}$ & $\begin{array}{c}\text { Ludman } \\
{[4]} \\
(\mathrm{N}=54)\end{array}$ & $\begin{array}{c}\text { Ruiz-García } \\
{[22]} \\
(\mathrm{N}=16)\end{array}$ & $\begin{array}{c}\text { Sopo } \\
{[5]} \\
(\mathrm{N}=66)\end{array}$ & $\begin{array}{c}\text { Vazquez-Ortiz } \\
{[8]} \\
(\mathrm{N}=81)\end{array}$ & $\begin{array}{c}\text { Vila } \\
{[10]} \\
(\mathrm{N}=21)\end{array}$ & $\begin{array}{c}\text { Mehr } \\
{[15]} \\
(\mathrm{N}=35)\end{array}$ \\
\hline Cow's milk & $44(70)$ & 67 (309) & $59(13)$ & $46(25)$ & $44(7)$ & $67(44)$ & $25.9(21)$ & - & $20(7)$ \\
\hline Soy & $41(66)$ & 41 (189) & $63(14)$ & $11(6)$ & $6(1)$ & $4(3)$ & - & - & $34(12)$ \\
\hline Rice & $23(36)$ & $19(88)$ & & $2(4)$ & $6(1)$ & $4(3)$ & $7.4(6)$ & $9.5(2)$ & 40 (14) \\
\hline Oat & $16(26)$ & $16(74)$ & - & $6(3)$ & - & - & - & $4.7(1)$ & $6(2)$ \\
\hline Fish & - & - & - & $15(8)$ & $31(5)$ & $12(8)$ & $54.3(44)$ & $85.7(18)$ & $3(1)$ \\
\hline Poultry & - & $4.5(21)$ & $4.5(1)$ & - & $6(1)$ & $3(2)$ & - & - & $3(1)$ \\
\hline Wheat & $1(2)$ & $10(46)$ & - & $11(6)$ & $6(1)$ & - & - & $4.7(1)$ & - \\
\hline Egg & - & $11(51)$ & - & $13(7)$ & - & $6(4)$ & $9.8(8)$ & - & - \\
\hline
\end{tabular}

aalues are shown as percentage (number of patients). 
Table 3. Percentage of Patients With Food Protein-Induced Enterocolitis Syndrome Reacting to 2 or More Foods

\begin{tabular}{lcc}
\hline USA & Caubet [10] & $35 \%$ \\
USA & Nowak-Wegrzyn [11] & $80 \%$ \\
USA & Ruffner [13] & $43 \%$ \\
Australia & Mehr [14] & $17 \%$ \\
Spain & Vila [9] & $9 \%$ \\
Spain & Ruiz-García [21] & $7 \%$ \\
Spain & Vazquez-Ortiz [8] & $1.2 \%$ \\
Italy & Sopo [5] & $15 \%$ \\
United Kingdom & Ludman [4] & $30 \%$ \\
\end{tabular}

\section{Pathophysiology}

Based on the reports by Freier et al [30] and Kuitunen et al [31], FPIES is presumed to be caused by the protein component of foods. Freier et al observed that 5 out of 6 infants presenting with vomiting related to $\mathrm{CM}$ formula reproduced these symptoms after being challenged with isolated ß-lactoglobulin (BLG). One infant reacted only to bovine serum albumin. The authors also reported 1 infant with a severe reaction after being challenged with BLG that had been boiled for 70 minutes and suggested that conformational epitopes do not play a role in FPIES. However, some patients with CM and egg FPIES tolerate these foods in baked form [32]. Kuitunen et al studied 54 children with diarrhea and failure to thrive related to $\mathrm{CM}$ formula. Eight infants were challenged with $\mathrm{CM}$ proteins, and casein and BLG were the main triggers of clinical manifestations.

The immune mechanisms responsible for FPIES remain unclear. FPIES is considered a T-cell--mediated disorder, where ingestion of food allergens causes local inflammation leading to increased intestinal permeability and fluid shift.

Mucosal biopsies from children with enteropathy/FPIES show a number of inflammatory features after food challenge, such as increased counts of intraepithelial lymphocytes, CD $4^{+}$ T cells, and plasma cells producing IgM and IgA [33], as well as clusters of eosinophils [34,35]. Eosinophils and CharcotLeyden crystals in stool samples have also been reported [36].

Moreover, a reduction in the expression of TGF- $\beta$ receptor 1 in the intestinal epithelium of children with challenge-proven CM-FPIES has been described compared with controls [34]. TGF- $\beta$ is a cytokine that induces T-cell suppression, promotes B-cell switching to IgA production, and preserves epithelial barrier function.

TNF- $\alpha$ is a proinflammatory molecule that induces intestinal permeability. In vitro studies have shown that peripheral blood mononuclear cells from children with FPIES produce more TNF- $\alpha$ than those from controls [37] or patients who had outgrown FPIES.

González-Delgado et al [37] also demonstrated a higher increase in expression of the HLA-DR molecule in dendritic cells (DC) from patients with fish-induced FPIES in the presence of 2 different fish extracts than in controls.
Goswami et al [38] recently reported activation of cells of the innate immune system after food challenge (eg, monocytes, neutrophils, eosinophils, and natural killer cells). This activation was not observed in children who had outgrown FPIES. Furthermore, a global loss of lymphocytes from the peripheral circulation was observed after positive food challenge, as was activation of $\mathrm{CD}^{+}, \mathrm{CD} 8+$, and $\gamma \delta$ lymphocytes, probably in response to cytokines and other mediators released during the acute reaction.

Data for the humoral immune profile are contradictory. In a comparison with controls, Konstantinou et al [39] found significantly lower levels of casein-specific $\operatorname{IgA}$, caseinspecific $\mathrm{IgG}$, and casein-specific IgG4 in infants with $\mathrm{CM}$ FPIES after CM challenge. Caubet et al [40] also reported lower levels of CM- and casein-specific IgG and caseinspecific IgG4 in patients with active CM FPIES than in those who tolerated CM. Shek et al [41] also observed significantly lower levels of CM-specific IgG4 in patients with CM FPIES than in controls. In contrast, McDonald et al [42] reported an increase in specific IgA and IgG in infants who reacted to $\mathrm{CM}$, egg, and soy on food challenge compared with those who tolerated these foods.

Interestingly, IL-10 levels have been found to be significantly higher in patients with resolved CM-FPIES, suggesting that expression of IL-10 could be associated with the development of tolerance in these patients [40]. Nevertheless, Kimura et al [43] found increased serum IL-10 in 2 positive open food challenges (OFCs).

An increase in serum IL-8 in patients with positive OFC results compared with patients with a negative OFC result has been also reported $[40,43]$. IL- 8 is a potent chemoattractant of neutrophils from peripheral blood into tissues and is also secreted by neutrophils, thus supporting the role of neutrophils in the pathogenesis of FPIES. In addition, higher casein-specific production of IL-9 was found in children with CM FPIES compared with children with IgE-mediated CM allergy. IL-9 may participate in the pathogenesis of FPIES by increasing intestinal mast cell numbers and influencing intestinal permeability [40].

Increased serum levels of IL-2 and IL-5 were recently reported after positive OFC results. IL-2 is a representative $\mathrm{T}_{\mathrm{H}} 1$ cytokine, while IL-5 is a $\mathrm{T}_{\mathrm{H}} 2$ cytokine that enhances the proliferation of eosinophils and promotes the development of eosinophilic inflammation in allergic disorders [43]. Furthermore, IL-2 and IL- 8 induce fever and increase C-reactive protein concentrations. Elevation of both cytokines might explain why some patients have fever after a positive OFC [43].

Further studies are needed to elucidate the role of these cytokines in the pathogenesis of FPIES.

Pathologic findings in patients with FPIES are summarized in Table 4.

\section{Diagnosis}

Affected infants experience 2 to 3 reactions (range, 1-10) before FPIES is considered. A mean delay of 12 months until the diagnosis of FPIES has been reported [4]. Diagnosis of FPIES, especially to solid foods, can be challenging and is 
Table 4. Pathologic Findings in Patients With Food Protein-Induced Enterocolitis Syndrome

\begin{tabular}{ll}
\hline Cellular findings & Peripheral blood eosinophilia, clusters of eosinophils in intestinal biopsies, eosinophils and Charcot-Leyden \\
& crystals in stool samples [34] \\
& Increased numbers of intraepithelial lymphocytes, increased number of CD4+, plasma cells producing IgM \\
& and IgA [36] \\
& Increased expression of HLA-DR in dendritic cells [35] \\
& Increased plasma cells producing IgM and IgA and eosinophils during milk exposure in the gastrointestinal tract [32,33] \\
& Activation of cells of the innate immune system (monocytes, eosinophils, natural killer cells, neutrophils) [38] \\
& Pan-T-cell activation and redistribution from the circulation after positive food challenge [38] \\
\hline Humoral responses & Lower levels of casein-IgG4 and casein-IgG in patients with active cow's milk food protein-induced \\
& enterocolitis syndrome than those who tolerate cow's milk [36,37] \\
& Contradictory results regarding food specific-IgA: increased [42] /decreased [39] \\
& Decreased secretion of IL-10 [40] \\
& Increased secretion of IL-8 [43) and IL-9 [40] \\
Cytokines & Increased TNF- $\alpha$ [36,37, 43] \\
& Decreased expression of TGF- $\beta$ receptors and decreased production of TGF- $\beta$ [37,41] \\
& Increased IP-10 [40] \\
& Increased IL-2 and IL-5 [43]
\end{tabular}

Abbreviation: HLA-DR, human leukocyte antigen-antigen D-related.

often delayed, probably owing to a low index of suspicion, absence of diagnostic tests, and the fact that many culprit foods (eg, vegetables, rice, and poultry meat) are traditionally not considered allergenic.

The clinical diagnostic criteria for FPIES over time are summarized in Table 5.

Powell [2] initially proposed diagnostic criteria for the chronic form of FPIES, which were subsequently modified to incorporate features of the acute form [44]. In 2013, Sopo et al [45] updated the criteria, mainly for the acute form, and suggested that the diagnosis could be established after 2 typical episodes of FPIES. The first international consensus guidelines on diagnosis and management of FPIES were recently published [46]. At present, the diagnosis of FPIES is based on a clinical history of typical characteristic signs and symptoms with improvement after withdrawal of the suspected trigger food. OFC can help to confirm the diagnosis if the history is unclear and there is a favorable risk-benefit ratio [46].

A variety of protocols for FPIES-related OFC have been published. Infante et al [15] perform OFC on 2 nonconsecutive days: on the first day, they give the child a single dose slightly less than $50 \%$ of the serving size for age. If tolerated and the child remains free of symptoms for 48 hours, a full serving is offered. All patients are observed for 4 hours after each OFC. Sopo et al [5] described 3 different protocols in Italy. Only 1 medical team placed an intravenous access before OFC. In this case, $0.4 \mathrm{~g} / \mathrm{kg}$ of protein divided into 3 equal doses was administered over 3 hours, and if no adverse reaction occured, a whole meal with the offending food was given and the patient remained under observation for 2 hours. The second protocol consisted of the administration of $50 \%$ of a serving for age followed by a 2 -hour observation period. If tolerance was confirmed, a second dose of $100 \%$ of the serving was given, followed by a 4-hour observation period. The third protocol started with $25 \%$ of the serving size followed by a 4 -hour clinical observation period; a dose equal to $50 \%$ of the serving was given, followed by another 4-hour observation period. Finally, the whole meal was given the day after, followed by a 4-hour clinical observation period.

Vazquez-Ortiz et at [8] administer $0.3 \mathrm{~g}$ of protein $/ \mathrm{kg}, 3$ $\mathrm{g}$ as the maximum dose, divided into 3 equal doses given at 90-minute intervals, except for CM, in which 7 consecutive doses are given at 90-minute intervals. An intravenous line is placed before the OFC starts.

We usually administer the full serving per age and size divided into 5 doses given every 20 minutes. Patients are under observation for at least 4 hours. We do not usually place an intravenous line, except in cases of severe previous reactions.

Current consensus is to administer $0.06 \mathrm{~g}$ to $0.6 \mathrm{~g}$ of protein $/ \mathrm{kg}$ ( 0.15 to $0.3 \mathrm{~g}$ protein $/ \mathrm{kg}$ if the patient has a history of severe reaction) in 3 equal doses over 30 minutes in order not to exceed a total dose of $3 \mathrm{~g}$ of protein or $10 \mathrm{~g}$ of total food (100 $\mathrm{mL}$ of liquid). Patients are observed for 4 to 6 hours [46]. Readily available intravenous hydration is advised during this procedure [46], although in our experience and that of others $[3,5]$, most reactions can be managed by oral rehydration.

Although the results of serum specific-IgE and skin prick tests with the suspected food are negative in most cases, some patients present food-specific IgE. This condition is known as atypical FPIES and has been reported more frequently in the USA and UK. Thus, in the USA, Caubet et al [11] reported atypical FPIES in $37 \%$ of patients with atypical FPIES, and in the UK, Ludman et al [4] reported the condition in 33\%. 
Table 5. Clinical Diagnostic Criteria for Food Protein-Induced Enterocolitis Syndrome Over Time and Actual Proposed Criteria

Powell, 1978 [2]

1. Onset before 2 months of age.

2. Manifestations: watery stools with mucus, blood, and leukocytes.

Peripheral polymorphonuclear leukocytosis.

3. Clinical manifestations resolve when the offending food is eliminated.

4. Reintroduction of offending food (OFC) leads to:

a. Diarrhea within 24 hours of challenge

b. Stools contain blood and leukocytes

c. Leukocytosis over 4000 cells/mm3, 6 to 8 hours postchallenge.

Powell, 1986 [44]

1. Removing of the offending food leads to disappearance of vomiting and diarrhea and of leukocytes and blood in stools.

2. No other causes for colitis.

3. Symptoms do not recur and weight gain is normal for 1 month on a low-antigen formula as the only dietary source.

4. Challenge with the offending food reproduces symptoms of vomiting within 1-3 hours and/or diarrhea within 4-10 hours.

Leonard and Nowak-Wegrzyn, 2012 [23]

1. Less than 9 months of age at initial diagnosis.

2. Repeated exposure to the offending food elicits gastrointestinal symptoms with no alternative cause.

3. Absence of symptoms suggesting an IgE-mediated reaction.

4. Removal of causative food results in resolution of symptoms.

5. Re-exposure to the offending food elicits typical symptoms within 4 hours.

Sopo et al, 2013 [45]

1. Age of presentation less than 2 years.

2. Exposure to the offending food elicits repetitive vomiting, pallor, and lethargy within 2-4 hours. Diarrhea may be present but later Symptoms usually resolve within 6 hours.

3. Absence of symptoms suggesting an IgE-mediated reaction.

4. Avoidance of the offending food results in resolution of symptoms.

5. Re-exposure to the offending food elicits typical symptoms within 2-4 hours. Two typical episodes are needed to establish the definitive diagnosis without the need to perform an OFC.

Consensus guidelines for the diagnosis and management of food protein-induced enterocolitis syndrome (Nowak-Wegrzyn et al, 2017 [46]

Acute FPIES

Major criterion

Vomiting in the 1-4 hour period after ingestion of the offending food and absence of classic IgE-mediated allergic skin or respiratory symptoms. Minor Criteria

1. A second (or more) episode of repetitive vomiting after eating the same suspected food

2. Episode of repetitive vomiting 1-4 hours after eating a different food

3. Extreme lethargy with any suspected reaction

4. Marked pallor with any suspected reaction

5. Need for emergency room visit with any suspected reaction

6. Need for intravenous fluid support with any suspected reaction

7. Diarrhea within 24 hours (usually 5-10 hours)

8. Hypotension

9. Hypothermia

The diagnosis of FPIES requires the major criterion and at least 3 minor criteria.

Chronic FPIES

Severe presentation: when the offending food is ingested in on a regular basis (eg, infant formula): intermittent and progressive vomiting and diarrhea (occasionally with blood) can develop, sometimes with dehydration and metabolic acidosis.

Milder presentation: lower doses of the culprit food (eg, solid foods or food allergens in breast milk) lead to intermittent vomiting, and/ or diarrhea, usually with poor weight gain/failure to thrive, but without dehydration of metabolic acidosis.

The most important criterion for chronic FPIES diagnosis is resolution of the symptoms within days after elimination of the offending food(s) and acute recurrence of symptoms when the food is reintroduced, onset of vomiting in 1-4 hours, diarrhea in 24 hours (usually 5-10 hours). 
Atypical FPIES is unusual in Italy and Spain: Sopo et al [5] found atypical FPIES in 3\% of Italian children, whereas in Spain, Ruiz et al [22] found 1 patient out of 16 to have foodspecific IgE. Zapatero et al [9] reported 1 out of 14 cases, Infante et al [15] reported 3 out of 80 patients, and VazquezOrtiz et al [8] reported no atypical FPIES in a large series of 81 patients. Consistent with these observations, we found negative SPT results and serum specific IgE in 21 children with FPIES caused by solid foods [10].

Patients with atypical FPIES have a more protracted course and an increased risk of immediate allergic reactions after ingestion of the offending food $[3,5,11]$. Therefore, testing specific IgE for the trigger food would be interesting during follow-up, before performing OFC, in patients with comorbid conditions such as IgE-mediated allergy to other foods and atopic dermatitis believed to be influenced by a food allergen; however, this is not recommended in the initial evaluation of a FPIES trigger. In patients with CM-induced FPIES, CM IgE levels should be measured before performing $\mathrm{OFC}$, given the risk of conversion to IgE-mediated CM allergy [46]. In cases of positive food-specific IgE, more gradual administration of increasing doses of food during OFC is recommended, with a longer observation period [47].

Given that FPIES is presumably T-cell-mediated, atopy patch testing (APT) was initially thought to be useful for the diagnosis of FPIES. In a series of 19 patients, Fogg et al [48] reported APT to have high sensitivity $(100 \%)$ and specificity (71\%). A subsequent study by the same group showed APT to have a $45 \%$ false-negative rate, and the authors concluded that APT was not useful for the diagnosis of FPIES [14]. Järvinen and Nowak-Wegrzyn [49] performed APT on children with FPIES before OFC to monitor development of tolerance. APT yielded low sensitivity (11.8\%), a positive predictive value of $40 \%$, and a negative predictive value of $54.5 \%$. Therefore, more studies are needed to determine the usefulness of APT for the diagnosis of FPIES.

Other determinations such as stool testing, endoscopy, and biopsy are not routinely recommended in patients with suspected FPIES, since the diagnosis is based on clinical criteria [46].

If the diagnosis of FPIES is not established during the acute FPIES reaction, the ill appearance of the patient may warrant laboratory studies to narrow the differential diagnosis,

Table 6. Differential Diagnosis of FPIES

\begin{tabular}{ll}
\hline Acute FPIES & Chronic FPIES \\
\hline Gastrointestinal viral infection & $\begin{array}{l}\text { Celiac disease } \\
\text { Proctocolitis }\end{array}$ \\
Sepsis & $\begin{array}{l}\text { Food protein-induced } \\
\text { enteropathy } \\
\text { Anaphylaxis }\end{array}$ \\
Eosinophilic \\
gastroenteropathies \\
Intussusception
\end{tabular}

Abbreviation: FPIES, food protein-induced enterocolitis syndrome which includes sepsis, gastroenteritis, bowel obstruction, celiac disease, inborn errors of metabolism, necrotizing enterocolitis, and even anaphylaxis. Leukocytosis with neutrophilia is a common finding in acute FPIES reactions [12,50]. Other findings include thrombocytosis [15], eosinophilia [51], metabolic acidosis, and methemoglobinemia [52]. A timedependent significant increase in C-reactive protein during acute episodes of FPIES was recently reported [50]. Stool samples may reveal leukocytes, frank or occult blood, and eosinophils. All these changes return to normal ranges once the reaction has resolved.

Chronic FPIES has to be distinguished from eosinophilic gastroenteritis, celiac disease, allergic proctocolitis, and food protein-induced enteropathy.

The differential diagnosis of FPIES is summarized in Table 6.

\section{Management}

Acute management of FPIES is based on rehydration. Oral rehydration at home or at a medical facility, when possible, is preferred. However, intravenous hydration is mandatory in severe cases with protracted emesis, lethargy, hypotension, or acidosis. In some cases, supplemental oxygen, vasopressors, and even methylene blue may be necessary.

Given that FPIES is a cell-mediated condition, intravenous methylprednisolone $(1 \mathrm{mg} / \mathrm{kg})$ is traditionally administered during the acute, severe reaction although no studies support this recommendation [53].

Two recent small case series by Holbrook et al [54] and Sopo et al [55] suggest a role for parenteral ondansetron in controlling acute symptoms.

Ondansetron is a serotonin 5-HT3 receptor antagonist that prevents postsurgical and chemotherapy-induced nausea and vomiting. It is also used to control vomiting during acute gastroenteritis [56]. Serotonin is mostly produced in the gastrointestinal tract and. It induces vomiting through vagal peripheric and central reflexes and stimulates peristalsis, gastric emptying, and secretion of liquid and electrolytes to the intestine.

The only relevant adverse effect of ondansetron is the risk of prolonged QT interval, which can lead to torsade de pointes, a potentially fatal arrhythmia. As this is a dose-dependent adverse effect, it has been recommended that a single >32-mg intravenous dose should be avoided. Patients with bradyarrhythmias and patients taking concomitant medications that prolong the QT interval are at greater risk [57].

Sopo et al [58] conducted a study comparing parenteral ondansetron with traditional therapy (intravenous fluids and methylprednisolone $[1 \mathrm{mg} / \mathrm{kg}]$ ) and found that only $19 \%$ of children treated with ondansetron continued vomiting compared with $93 \%$ of children treated with traditional therapy. Moreover, nonresponders treated with ondansetron had fewer episodes of vomiting than those receiving traditional therapy, although the difference was not significant. In addition, the percentage of children admitted to hospital overnight was significantly lower in the ondansetron group. Therefore, the authors conclude that parenteral ondansetron is more effective than intravenous corticosteroids for resolution of the acute symptoms of FPIES. No significant differences were 
Table 7. Proposed Doses of Ondansetron as Treatment of Acute Food Protein-Induced Enterocolitis Syndrome

\begin{tabular}{|c|c|c|c|c|c|}
\hline & Intravenous & Intramuscular & IV/IM & \multicolumn{2}{|c|}{ Oral (Lingual) } \\
\hline & & & & & \\
\hline Sopo et al [55] & & $0.2 \mathrm{mg} / \mathrm{kg}$ & & & \\
\hline Sopo et al [58] & & & $0.15-0.2 \mathrm{mg} / \mathrm{kg}$ & & \\
\hline $\begin{array}{l}\text { Vila et al } \\
\text { (personal communication) }\end{array}$ & & & & $\begin{array}{c}\text { Body weight } \\
8-15 \mathrm{~kg} \\
16-30 \mathrm{~kg} \\
>30 \mathrm{~kg}\end{array}$ & $\begin{array}{l}\text { Dose } \\
2 \mathrm{mg} \\
4 \mathrm{mg} \\
8 \mathrm{mg}\end{array}$ \\
\hline
\end{tabular}

found between the intramuscular and intravenous routes of administration of ondansetron.

Leonard [23] reported on the effectiveness of homeadministered liquid ondansetron in patients with FPIES [23]. Our personal experience with this route of administration was positive in 7 patients who developed vomiting on OFC at our clinic. Only 1 patient continued to vomit after the first dose of ondansetron and had to be admitted to the emergency room for oral rehydration. The proposed dosage is extrapolated from that recommended for acute gastroenteritis (Table 7).

\section{Long-term Management and Prognosis}

Strict avoidance of the trigger food is the cornerstone of long-term management. After elimination of the offending food, acute FPIES usually resolves within 4-12 hours, whereas chronic FPIES resolves within 3 to 10 days [59].

Breastfeeding should be encouraged in infants with $\mathrm{CM} /$ soy FPIES, and an extensive hydrolyzed casein-based formula is usually recommended, although up to $11 \%-40 \%$ of infants may not tolerate it and require an amino acid-based formula $[11,12]$. Since there are only small case series reporting tolerance to baked egg and milk [32], it is recommended to introduce them in the clinical setting under physician supervision.

As for solid foods, some patients tolerate other foods belonging to the same family as the offending one. Our group [10] and Sopo et al [5], respectively, reported that $60 \%$ and $21 \%$ of children with fish FPIES tolerated fish other than the one causing the reaction. Based on our experience, and especially in the case of fish-induced FPIES, OFC at diagnosis with other foods from the same family as the offending food would help to avoid unnecessary dietary restrictions.

Prognosis is good, with most children tolerating the offending food over time. However, there are some differences, depending on the type of food. Children with fish-induced FPIES outgrow it later than those with CM-, soy-, or riceinduced FPIES [3,5,8-11,13,14-16,24,35,55], although, as reported by Caubet et al [11], soy FPIES may be outgrown by as late as 6 years of age (Table 8 ).

OFC is recommended every $1.5-2$ years to confirm tolerance to the offending food, although deferring egg and fish challenges until age 5 years has been suggested [24].

Kimura et al [60] recently studied 32 patients with FPIES caused by $\mathrm{CM}$ and found a significant positive correlation

Table 8. Age of Food Protein-Induced Enterocolitis Syndrome Resolution by Cohort

\begin{tabular}{|c|c|c|c|c|c|}
\hline & Cow's Milk & Soy & Rice/Grains & Fish & Egg \\
\hline González-Delgado et al [35] & & & & $>6 y$ & \\
\hline Sopo et al [5] & $2 \mathrm{y}$ & & & $9 y$ & \\
\hline Vila et al [9] & & & & $>5 \mathrm{y}$ & \\
\hline Ruffner et al [13] & & & $3.5 \mathrm{y}$ & & \\
\hline Vazquez-Ortiz et al [8] & $2.4 \mathrm{y}$ & & & $5 \mathrm{y}$ & $>5 y$ \\
\hline Nowak-Wegrzyn et al [11] & $2 y$ & $>3 y$ & $2 \mathrm{y}$ & & \\
\hline Caubet et al [10] & $5 y$ & $6.7 \mathrm{y}$ & $4.7 \mathrm{y}$ & & \\
\hline Katz et al [3] & $3 y$ & & & & \\
\hline Mehr et al [14] & & & $3 y$ & & \\
\hline Lee et al [24] & $4 \mathrm{y}$ & & $4 \mathrm{y}$ & $>5 \mathrm{y}$ & $>5 \mathrm{y}$ \\
\hline Huang et al [16] & $1 \mathrm{y}$ & & $7.8 \mathrm{mo}$ & & \\
\hline Karefylaki et al [55] & & & & $>4 y$ & \\
\hline Infante et al [15] & & & & $5 y$ & \\
\hline
\end{tabular}


between the time of acquisition of tolerance and the level of serum C-reactive protein at onset and a significant negative correlation with the percentage of eosinophils in peripheral blood at onset, thus suggesting that $\mathrm{C}$-reactive protein could be a useful parameter of poor prognosis and that eosinophilia could be used as a marker of good prognosis.

Older age at the time of the initial FPIES episode and diagnosis and presence of specific IgE to the triggering food have been associated with slower achievement of tolerance $[11,24]$.

The issue of whether common FPIES foods should be prophylactically avoided in infants with a previous history of FPIES is controversial. Owing to the high rates of cosensitization to CM and soy in the USA, Ruffner et al [14] and Caubet et al [11] recommend avoidance of soy formulas in infants with CM-induced FPIES. Cohort studies from Australia, Italy, and Israel report much lower rates of simultaneous CM and soy FPIES, suggesting that soy could be an alternative for infants with CM FPIES [62].

Children with CM- or soy-induced FPIES may also be more likely to react to solid foods, mainly rice and oat, and although grains, legumes, and poultry should be avoided in the first year of life [62], current early feeding guidelines do not recommend delaying the introduction of complementary foods after 6 months of life because of a history of previous FPIES [46]. A sequence for introducing solid foods after 6 months of age starting with fruits and vegetables followed by red meats and then cereal grains (considering poultry, banana, green pea, rice, and oat as high risk foods) has been proposed [46,59]. Sopo et al [46] propose supervised OFCs to various solids as a way of excluding the risk of severe reactions to small amounts, followed by gradual build-up to regular age-appropriate servings at home.

Mothers are not recommended to avoid trigger foods when nursing unless a reaction is documented after breastfeeding [63].

In summary, FPIES is a non-IgE-mediated type of gastrointestinal food hypersensitivity that predominantly affects infants and young children. The foods most frequently implicated are CM, soy formula, grains, and fish, depending on the geographic area. Diagnosis is based on clinical manifestations and requires a high index of suspicion, since we still lack an effective diagnostic laboratory tool. Early recognition of FPIES and removal of the offending food are mandatory to prevent new acute episodes and/or chronic manifestations such as failure to thrive.

Prognosis is usually good, with most children tolerating foods before 6 years of age. More protracted courses are seen in infants with fish-induced FPIES and in those patients who develop food-specific IgE.

Further studies on pathophysiology, diagnostic tools, and the natural course of FPIES are warranted.

\section{Acknowledgments}

I am very grateful to Maria Jesus Fernandez Hermida and Isabel Cabanas for their excellent work with the oral food challenges and for their dedication to the patients.

\section{Funding}

The author declares that no funding was received for the present study.

\section{Conflicts of Interest}

The author declares that she has not conflicts of interest.

\section{References}

1. Gryboski J. Gastrointestinal milk allergy in infancy. Pediatrics. 1967:40:354-62.

2. Powell GK. Milk- and soy-induced enterocolitis of infancy. Clinical features and standardization of challenge. J Pediatr. 1978;93:553-60.

3. Katz Y, Goldberg MR, Rajuan N, Cohen A, Leshno M. The prevalence and natural course of food proteininduced enterocolitis syndrome to CM: a large-scale, prospective population-based study. J Allergy Clin Immunol. 2011;127:647-53. e1-3

4. Ludman S, Harmon M, Whiting D, du Toit G. Clinical presentation and referral characteristics of food proteininduced enterocolitis syndrome in the United Kingdom. Ann Allergy Asthma Immunol. 2014;113 (3):290-4.

5. Sopo M, Giorgio V, Dello lacono I, Novembre E, Mori F, Onesimo R. A multicenter retrospective study of 66 Italian children with food protein-induced enterocolitis syndrome: different management for different phenotypes. Clin Exp Allergy. 2012;42:1257-65.

6. Mehr S, Frith K, Barnes E, Campbell D; FPIES Study Group. Food protein-induced enterocolitis syndrome in Australia: a population-based study, 2012-2014. J Allergy Clin Immunol. 2017;140(5):1323-30.

7. Fernandes B, Boyle R, Gore C, Simpson A, Custovic A. Food protein-induced enterocolitis syndrome can occur in adults. J Allergy Clin Immunol. 2012;130 (5):1199-200.

8. Vazquez-Ortiz $M$, Machinena A, Dominguez 0 , Alvaro $M$, Calvo-Campoverde K, Giner MT, et al. Food protein-induced enterocolitis syndrome to fish and egg usually resolves by age 5 years in Spanish children. J Allergy Clin Immunol Pract. 2017;5(2):512-5.

9. Zapatero Remón L, Alonso Lebrero E, Martín Fernández E, Martínez Molero Ml. Food protein-induced enterocolitis syndrome caused by fish. Allergol et Immunopathol. 2005;33(6):312-6.

10. Vila L, Garcia V, Rial MJ, Novoa E, Cacharron T. Fish is a major trigger of solid food protein-induced enterocolitis syndrome in Spanish children. J Allergy Clin Immunol Pract. 2015;3(4):621-3.

11. Caubet JC, Ford LS, Sickles L, Jarvinen KM, Sicherer SH, Sampson HA. Clinical features and resolution of food proteininduced enterocolitis syndrome: 10-year experience. J Allergy Clin Immunol. 2014;134:382-9.

12. Nowak-Wegrzyn A, Sampson HA, Wood RA, Sicherer SH. Food protein-induced enterocolitis syndrome caused by solid food proteins Pediatrics. 2003;111:829-35. 
13. Mehr SS, Kakakios AM, Kemp AS. Rice: a common and severe cause of food protein-induced enterocolitis syndrome. Arch Dis Child. 2009;94:220-3.

14. Ruffner MA, Ruymann K, Barni S, Cianferoni A, BrownWhitehorn T, Spergel JM. J Allergy Clin Immunol Pract. 2013;1:343-9.

15. Infante S, Marco-Martín G, Sánchez-Domínguez M, RodríguezFernández A, Fuentes-Aparicio V, Alvarez-Perea A, et al. Food protein-induced enterocolitis syndrome by fish: Not necessarily a restricted diet. Allergy. 2017 Oct 20. doi: 10.1111/all.13336.

16. Sopo SM, Monaco S, Badina L, Barni S, Longo G, Novembre $E$, et al. Food protein-induced enterocolitis syndrome caused by fish and/or shellfish in Italy. Pediatr Allergy Immunol. 2015:26:731-6.

17. Hwang JB, Sohn SM, Kim AS. Prospective follow-up food challenge in food protein-induced enterocolitis syndrome. Arch Dis Child. 2009;94:425-8.

18. Nomura I, Morita H, Hosokawa S, Hoshina H, Fukuie $T$, Watanabe $M$, et al. Four distinct subtypes of non-lgEmediated gastrointestinal food allergies in neonates and infants, distinguished by their initial symptoms. J Allergy Clin Immunol. 2011;127:685-8 e1-8.

19. Miceli Sopo S, Monaco S, Greco M, Scala G. Chronic food protein-induced enterocolitis syndrome caused by cow's milk proteins passed through breast milk. Int Arch Allergy Immunol. 2014;164(3):207-9.

20. Kaya A, Toyran M, Civelek E, Mirishoglu ED, Kirsaclioglu CT, Kocabas CN. Food protein-induced enterocolitis syndrome in two exclusively breastfed infants. Pediatr Allergy Immunol. 2016;27(7):749-50

21. Tan J, Campbell D, Mehr S. Food protein-induced enterocolitis syndrome in an exclusively breast-fed infant- un uncommon entity. J Allergy Clin Immunol. 2012;129:873.

22. Ruiz-García M, Escudero Díaz C, Sánchez García S, Rodriguez del Río P, Ibañez MD. Diagnosis and natural history of food protein-induced enterocolitis syndrome in children from a tertiary hospital in Central Spain. J Invest Allergol Clin Immunol. 2014;24(5):352-370.

23. Leonard S, Nowak-Wegrzyn A. Food Protein-Induced Enterocolitis Syndrome. Pediatr Clin N Am. 2015;62:1463-77.

24. Lee $E$, Campbell D, Barnes E, Mehr S. Resolution of acute food protein-induced enterocolitis syndrome in children. J Allergy Clin Immunol Pract. 2016;5(2):486-8.e1

25. Serafini S, Bergman M, Nowak-Wegrzyn A, Eigenmann $P$, Caubet C. A case of food protein-induced enterocolitis syndrome to mushrooms challenging currently used diagnostic criteria. J Allergy Clin Immunol Pract. 2014;3(1):136-7.

26. Hwang JB, Kang KJ, Kang YN, Kim AS. Probiotic gastrointestinal allergic reaction caused by Saccharomyces boulardii. Ann Allergy Asthma Immunol. 2009;103(1):87-8.

27. Zubrinich C, Hew M, O'Hehir R. Egg provoked food proteininduced enterocolitis-like syndrome in adults. Clin Case Rep. 2016:4(9):899-901

28. Tan JA, Smith WB. Non-IgE-mediated gastrointestinal food hypersensitivity syndrome in adults. J Allergy Clin Immunol Pract. 2014;2:355-357.e1

29. Mehr S, Frith K, Campbell D. Epidemiology of food proteininduced enterocolitis syndrome. Curr Opin Allergy Clin Immunol. 2014;14:208-16.
30. Freier S, Kletter B, Gery I, Lebenthal E, Geifman M. Intolerance to milk protein. J Pediatrics. 1969;75;4:623-31.

31. Kuitunen P, Visakorpi JK, Savilahti E, Pelkonen P. Malabsorption syndrome with cow's milk intolerance. Clinical findings and course in 54 cases. Arch Dis Child. 1975;50:351-6.

32. Sopo M, Buonsenso D, Monaco S. Food protein-induced enterocolitis syndrome (FPIES) and well cooked foods: a working hypothesis. Allergol Immunopathol (Madr). 2013;41:346-8.

33. Nagata S, Yamashiro Y, Ohtsuka Y. Quantitative analysis and immunohistochemical studies on small intestinal mucosa of food sensitive enterophaty. J Pediatr Gastroenterol Nutr. 1995;20(1):44-8.

34. Fontaine JL, Navarro J. Small intestinal biopsy in cow's milk protein allergy in infancy. Arch Dis Child. 1975;50:357-62.

35. Savilahti E. Immunochemical study of the malabsortion syndrome with cow's milk intolerance. Gut. 1973;14:491501.

36. Chung HL, Hwang JB, Park JJ, Kim SG. Expression of transforming growth factor b1, transforming growth factor type I and II receptors and TNF-alfa in the mucosa of the small intestine in infants with food protein-induced enterocolitis syndrome. J Allergy Clin Immunol. 2002;109:150-4.

37. González-Delgado P, Caparrós E, Moreno MV, Clemente F, Flores E, Velásquez $L$, et al. Clinical and immunological characteristics of a pediatric population with food proteininduced enterocolitis syndrome (FPIES) to fish. Pediatr Allergy Immunol. 2016;27:269-75.

38. Goswami R, Blazquez AB, Kosy R, Rahman A, Nowak-Wegrzyn $A$, Berin C. Systemic innate immune activation in food proteininduced enterocolitis syndrome. J Allergy Clin Immunol. 2017;139:1885-96.

39. Konstantinou G, Bencharitiwong R, Grishin A, Caubet JC, Bardina $L$, Sicherer $S$, et al. The role of casein-specific $\lg A$ and TGF-beta in children with food-protein-induced enterocolitis syndrome to milk. Pediatr Allergy Immunol. 2015;25:651-6.

40. Caubet JC, Bencharitiwong R, Ross A, Sampson HA, Berin MD, Nowak-Wegrzyn A. Humoral and cellular responses to casein in patients with food protein-induced enterocolitis to cow's milk. J Allergy Clin Immunol. 2017;139(2):572-83.

41. Shek LP, Bardina L, Castro R, Sampson HA, Beyer K. Humoral and cellular responses to cow milk proteins in patients with milk-induced IgE-mediated and non-IgE mediated disorders. Allergy. 2005;60:912-9.

42. McDonald PJ, Goldblum RM, Van Sickle GJ, Powell GK. Food protein-induced enterocolitis: altered antibody response to ingested antigen. Pediatr Res. 1984;18:751-5.

43. Kimura M, Ito Y, Shimomura M, Morishita H, Meguro T, Adachi $Y$, et al. Cytokine profile after oral food challenge in infants with food protein-induced enterocolitis syndrome. Allergol Int. 2017 doi: 10.1016/j.alit.2016.12.001

44. Powell GK. Food protein-induced enterocolitis of infancy: differential diagnosis and management. Compr Ther. 1986;12:28-37

45. Sopo M, Greco M, Monaco S, Tripodi S, Calvani M. Food protein-induced enterocolitis syndrome: from practice to theory. Exp Rev Clin Immunol. 2013;9:707-15.

46. Nowak-Wegrzyn A, Chehade M, Groetch ME, Spergel JM, Wood RA, Allen K, et al. International consensus guidelines for the diagnosis and management of food protein-induced enterocolitis syndrome: Executive summary-Workgroup 
Report of the Adverse Reactions to Foods Committee, American Academy of Allergy, Asthma \& Immunology. J Allergy Clin Immunol. 2017;139:1111-26.

47. Nowak-Wegrzyn A, Assa'ad AH, Bahna SL, Bock SA, Sicherer SH, Teuber SS. Work Group report: oral food challenge testing. J Allergy Clin Immunol. 2009;123:\$365-83.

48. Fogg MI, Brown-WhitehornTA, Pawlowski NA et al. Atopy patch test for the diagnosis of food protein-induced enterocolitis syndrome. Pediatr Allergy Immunol. 2006;17:351-5.

49. Järvinen KM, Nowak-Wegrzyn A, Caubet JC, Sickles L, Ford LS, Sampson HA, et al. Poor utility of atopy patch test in predicting tolerance development in food protein-induced enterocolitis syndrome. Ann Allegy Clin Immunol. 2012;109: 221-2.

50. Pecora V, Prencipe G, Valluci $R$, Dahdah L, Insalaco A, Cianferoni $A$, et al. Inflammatory events during Food ProteinInduced Enterocolitis Syndrome reactions. Pediatr Allergy Immunol. 2017 Apr 4. doi: 10.1111/pai.12723

51. Kimura $M$, Shimomura $M$, Morishita $H$, Meguro $T$, Seto S. Eosinophilia in infants with food protein-induced enterocolitis syndrome in Japan. Allergol Int. 2016. pii:S1323-8930(16);30109-5

52. Murray K CD. Dietary protein intolerance in infants with transient methemoglobinemia and diarrhea. J Pediatr. 1993;122:90-2.

53. Sicherer SH. Food protein-induced enterocolitis syndrome: case presentations and management lessons. J Allergy Clin Immunol. 2005;115:149-56.

54. Holbrook T, Keet CA, Frischmeyer-Guerreiro PA, Wood RA. Use of ondasetron for food protein-induced enterocolitis syndrome. J Allergy Clin Immunol. 2013;135 (5):1219-20.

55. Sopo SM, Battista A, Greco M, Monaco S. Ondansetron for food protein-induced enterocolitis syndrome. Int Arch Allergy Immunol. 2014;164:137-9.

56. Tomasik E, Ziółkowska E, Kołodziej M, Szajewska H. Systematic review with meta-analysis: ondansetron for vomiting in children with acute gastroenteritis. Aliment Pharmacol Ther. 2016 Sep;44(5):438-46.

57. Doggrell SA1, Hancox JC. Cardiac safety concerns for ondansetron, an antiemetic commonly used for nausea linked to cancer treatment and following anaesthesia. Expert Opin Drug Saf. 2013 May;12(3):421-31.

58. Sopo SM, Bersani G, Monaco S, Cerchiara G, Lee E, Campbell D, et al. Ondansetron in acute food protein-induced enterocolitis syndrome, a retrospective case-control study. Allergy. 2016; DOI: 10.1111/all.13033.

59. Nowak-Wegrzyn A, Jarocka-Cyrta E, Moschione Castro. Food Protein-Induced Enterocolitis Syndrome. J Invest Allergol Clin Immunol. 2017;27(1):1-18.

60. Kimura M, Shimomura M, Morishita H, Meguro T. Prognosis of infantile food protein-induced enterocolitis syndrome in Japan. Pediatr Int. 2017 Apr 22. doi: 10.1111/ped.13305.

61. Karefylaki S, Gustafsson D. Recovery from food proteininduced enterocolitis syndrome caused by fish. Pediatr Allergy Immunol. 2016;27:105-6

62. Järvinen KM, Nowak-Wegrzyn A. Food Protein-Induced Enterocolitis Syndrome (FPIES): Current Management Strategies and Review of the literature. J Allergy Clin Immunol Pract. 2013;1:317-22.

63. Leonard S, Chehade M. Food Protein-Induced Enterocolitis Syndrome. J Allergy Clin Immunol Pract 2017

64. Sicherer SH, Eigenmann PA, Sampson HA. Clinical features of food protein-induced enterocolitis syndrome. J Pediatr. 1998;133:214-9. Manuscript received June 26, 2017; accepted for
publication July 26, 2017 .

\section{- Leticia Vila Sexto}

Pediatric Allergy Department

Children's Hospital Teresa Herrera

Xubias, s/n

15006 A Coruña, Spain

E-mail: leticia.vila.sexto@sergas.es 